balancing equities such as these, the court should allow the petition, using its equitable powers thereafter to insure that any proceeds recovered inure to the benefit of creditors.

\title{
DEFERRED POSTING UNDER THE PROPOSED COMMERCIAL CODE
}

WHEN the holder of a check presents it at the drawee bank, he receives in exchange cash or a credit to his account. Most courts consider the bank's payment or credit final and irrevocable ${ }^{1}$ because the paying teller has opportunity to investigate the drawer's account as to signature, amount of funds, or notices which might stop payment of the check. ${ }^{2}$ But when the

1. Checks drawn on the bank of deposit and received over the counter, deposited by customers or cashed for holders, are considered paid when the customer's account is credited or when the holder receives cash. See, e.g., National Bank v. Burlihardt, 100

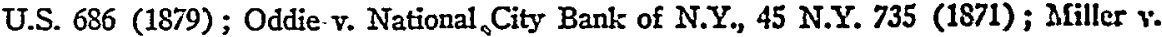
Chatham Nat. Bank, 126 Misc. 559, 214 N.Y. Supp. 76 (Sup. Ct. 1926). But ef. National Gold Bank \& Trust Co. v. M1cDonald, 51 Cal. 64 (1875) (entry of credit in depositor's bank-book by receiving teller does not by itself amount to an acceptance of the checls as cash) ; National Loan \& Exchange Bank of Columbia v. Lachovitz, 131 S.C. 432, 128 S.E. 10. (1925) (over the counter payment recovered where bank mistakenly paid after receipt of stop-order).

2. "A check of itself does not operate as an assignment of any part of the funds to the credit of the drawer with the bank, and the bank is not liable to the holder unless and until it accepts or certifies the check." Negotiable Instrusents IAW \$189. For this reason payment of the check may be stopped if notice is sent the drawee bank before the bank pays the check. See pages 962-3 infra. See Burrows v. Burrows, 240 dFass. 485, 137 N.E. 923 (1922) (death of drawer before presentment revokes check given as gift to payee) ; United States Nat. Bank v. First Trust \& Savings Bank, 60 Ore 266, 119 Pac. 343 (1911) (bolder denied recovery against drawee for refusing to pay after stop-arder); Tibby. Bros. Glass Co. v. Farmers \& M. Bank, 220 Pa. 1, 69 Atl. 280 (1908) (payee has no claim to funds because checks do not operate as an assignment). But ef. First Nat. Bank v. O'Byrne, 177 IIl. App. 473 (1st Dist. 1913) (check drawn for entire amount of deposit as gift causa nuortis held an assignment). Cases are collected in Note, \&4 A.L.R. 412 (1933). Prior to the Negotiable Instruments Law the minority rule held that a checl: was an assignment as soon as it was issued to the payee and that the payee's claim to the funds was superior to the rights of the drawer or of those claiming against or through him. See cases collected in Note, 5 A.L.R. 1667 (1920).

A certified check is a representation by the bank that the amount of money stated in the body of the check will be set aside for payment upon proper indorsement. Thus, the instrument after certification operates as an assignment. Blalie v. Familton Dime Sav. Bank, 29 Ohio Cir. Rep. 465 (1st Cir. 1907) (drawer's stop-order ineffective). But of. National Reserve Bank of New York v. Corn Exchange Bank, 171 App. Div. 195, 157 N.Y. Supp. 316 (1st Dep't 1916) (certification does not warrant the genuineness of the body of the check and payment of a raised check may be revoked). Cases are collected in 1 MORSE, Banks ANd BANknNg \$399 (6th ed. 1928). Where the drawer provides special deposits to cover particular checks, they operate as an assignment. Dolph v. Cross, 153 Iowa 289, 133 N.W. 669 (1911); Gruenther v. Bank of Mlonroe, 90 Neb. 280, 133 N.W. 402 (1911). 
holder deposits the check in a bank other than the drawee bank, a different rule applies. The credit which the holder obtained from the depositary bank is not final. He usually may not draw against it ${ }^{3}$ until the check has gone through the clearing system ${ }^{4}$ and the drawee bank has finally credited his depositary bank with the amount. Until this time the holder not only must forbear use of the fund, ${ }^{5}$ but he is also subject to the risk that payment will be delayed ${ }^{6}$ through bank failure, ${ }_{7}^{7}$ or notices of stop pay-

3. The bank ordinarily will not permit these funds to be withdrawn until final pay" ment is secured because of the risk that the check may be dishonored. While the customer may be required to refund, there is always the threat that he will have insufficient funds to cover the amount. See Kane v. First Nat. Bank of El Paso, 56 F.2d 534 (5th Cir. 1932). To the effect that permitting withdrawals constitutes a loan from the bank without interest charged and for arguments pro and con the advisability of banks allowing immediate withdrawal, see Moore, Sussman \& Corstvet, Drazeing Against Uncollccicd Checks: I, 45 YALE L.J. 1, 16-21 (1935).

The risks which banks face when permitting their customers to draw upon uncollected funds are not present when a large and reliable corporation is involved. Customers of this type keep large balances in their various accounts and the risk that they will be unable to refund the amount withdrawn if the check is dishonored, is negligible. Thus, some large banks permit their wealthier customers to draw upon uncollected funds. But this practice is the exception rather than the rule.

Whether withdrawal is permitted or not the bank will usually be able to charge backs the amount credited or require the customer to refund by virtue of notices printed on the deposit slip or pass-book to the effect that the bank credits the customer's account subject to final payment (by the drawee) and reserves the right to charge back beiore final payment.

For arguments in favor of permitting holders to draw immediately, see Moore, Sussman \& Corstvet, supra at 17,21 .

4. After the depositary bank temporarily credits its customer, it routes the check to the appropriate drawee bank. If the drawee is located in the same city the check will probably be sent through the clearing house. But where the drawee is an out-of-town bank the check will be sent either directly to it or through correspondent banks first. For more detailed description of the clearing and collection of checks, see Leary, Dcfcrrcd Posting and Delayed Retums-The Current Check Collection Problem, 62 HARv. L. REv. 905, 907-15 (1949).

5. The delay varies with the distance between the drawee and depositary banks. Most banks have availability schedules which are sets of rules for classifying checks with reference to the points on which they are drawn so as to determine at what time the holder may use the funds. The time specified is based upon the average time required for checks to reach the drawee bank by mail and includes the time within which the drawee may dishonor. See Moore, Sussman \& Corstvet, supra note 3, at 19-21.

6. Since a check does not operate as an assignment of funds, payment of the check may be stopped. See note 2 supra. The holder will then have to pursue the drawer on the underlying transaction. Rarely in these circumstances will the debt be paid promptly: (1) if the drawer stopped payment there is some dispute, or (2) if the drawer's account was garnished by creditors, he probably will not have funds to pay the holder, or (3) if the drawer died, the holder must settle with the estate, often a tedious procedurc. If litigation ensues, the holder will encounter considerable delay in realizing any payment.

7. Where a bank fails only those owners of checks to whom the bank is obligated to pay are protected by Federal Deposit Insurance. 12 Code FEd. ReGs. $\$ 330.2$ (Supp. 1946). Thus, when the drawee fails, the holder is protected by insurance only if the bank 
ment, ${ }^{8}$ garnishment, ${ }^{9}$ or the drawer's death. ${ }^{10}$ Thus, the drawee bank's irrevocable credit of the check determines the holder's risk period.

is obligated to pay, i.e., has accepted or has finally credited the check to the correspondent. Since final payment is extended to the next day, the holder's insurance coverage is put off that much longer. The drawee having failed before payment, credits will be reversed by all intermediate banks or clearing houses and the holder's credit at the depositary bank: will be charged back against him.

Extending the time for securing final credits in all banks also increases the risk that banks other than the drawee may fail, leaving the holder unprotected. See generally, Bogert, Failed Banks, Collection Items, and Trust Preferences, 29 MIIcr. L. REv. 545 (1931); Moore, Sussman \& Corstvet, supra note 3 at 22-35; Steffen, The Check Collection disudle, 10 TULANE L. REv. 537 (1936).

8. That a drawer can effectively order the drawee bank to stop payment before the check has been accepted, certified or paid is a firmly anchored proposition. Florence Mining Co. v. Brown, 124 U.S. 385 (1888); Tremont Trust Co. v. Buracl; 235 Mrass. 398, 126 N.E. 782 (1920) ; Mriller v. Chatham Nat. Bank, 126 Misc. 559, 214 N.Y. Supp. 76 (Sup. Ct. 1926) ; Steiner v. Germantown Trust Co., 104 Pa. Super. 38,158 Atl. 180 (1932). Cases are collected in 5 Míchis, Banks and Banking 359 (1932); 1 MIorse, Banks and Banking $\$ \$ 397-99$ (6th ed. 1928). And see Mloore, Sussman \& Brand, Legal and Institutional Methods Applied to Orders to Stop Payment of Chechs-I. Legal Mlethod, 42 YALE L.J. 817 (1933). If the bank pays regardless of a stop-order received before final credit or payment, it cannot recover from the holder and according to the majority view is liable to the drawer. See Pease \& Dwyer v. State Nat. Bank, 144 Tenn. 693, 8s S.W. 172 (1905). Contra: Foster v. Federal Reserve Bank of Philadelphia, 113 F.2d 326 (3d Cir. 1940). There is, however, a growing tendency to protect the drawee bank if it can justify its unauthorized payment by showing that such payment discharged a valid debt owing by the drawer to the payee. See cases discussed in Notes, 45 YALE L.J. 1134 (1936) ; 40 HaRv. L. Rev. 110 (1926). For an excellent analysis of the banl's position if it disobeys the stop-order, see Comment, 39 Yale L.J. 542 (1930). As to depositor contracts in which the drawer purports to waive his rights against the drawce for paying a check over a stop-order, see Note, 9 OHIo St. L.J. 543 (1948).

The holder is not remediless when payment on a check is stopped. The drawer cannot avoid genuine liability to the holder after stopping payment. If the drawer has no defenses, he remains liable both on the check and on the underlying transaction. Sce Alchian v. MiacDonald, 40 Cal. App. 505, 181 Pac. 77 (1st App. Dist. 1919) (stopping payment does not discharge the liability of the maker to the holder); Schirm $v$. Wieman, 103 Md. 541 (1906) (if the consideration for a check is legal, the drawer remains liable to payee on the instrument after stopping payment).

9. A creditor of the drawer, who attaches the drawer's funds, has a right to those funds superior to the holder whose check is not accepted or paid before the bank reccives notice of attachment. Wileman v. King, 120 Miss. 392, 82 So. 265 (1919); Holbrook v. Payne, 151 Mass. 383, 24 N.E. 210 (1890). Cases are collected in Notes, 50 A.L.R. 403 (1927) ; 84 A.L.R. 412 (1933).

10. A bank's authority to pay a check is revoled by the death of the drawer and a bank paying the check after notice of death is liable to the drawer's estate. Bridewell $v$. Clay, 185 S.W.2d 170 (Tex. Civ. App. 1944); Dixon Shoe Co. v. Mfoen, 203 Wis. 3S9, 243 N.W. 327 (1932); Sneider v. Bank of Italy, 184 Cal. 595, 194 Pac. 1021 (1920). Where the bank pays after death but before notice, the payment is valid. Glennan v. Rochester Trust \& Safe Deposit Co., 209 N.Y. 12, 102 N.E. 537 (1913); Chrzanowslaz v. Corn Exchange Bank, 173 App. Div. 285, 159 N.Y. Supp. 385 (1st Dep't 1916) aff'd arithout opinion, 225 N.Y. 728,122 N.E. 877 (1919). 
- To prevent undue extension of that risk period, the pre-war banking practice required drawee banks irrevocably to credit correspondent banks for demand items on the day of receipt." But this rule has been substantially changed in recent years. Increased use of checks and the war time manpower shortage sorely taxed bookkeeping departments, ${ }^{12}$ which were required to examine and post ${ }^{13}$ all items before the brief deadline for final credit. Errors caused by haste were comparatively frequent. Consequently, thirty-four states have enacted the American Bankers Association's Model Deferred Posting Statute, ${ }^{14}$ which allows drawee banks

Arguments against this rule are summarized by Morse, who calls the rule a "perversion of reason" in 1 MORSE, BANKS AND BANKING $\$ 400$ (6th ed. 1928).

For the Uniform Commercial Code's provision with respect to drawer's death and the bank's authority to pay, see note 20 infra.

11. Checks received for payment through the clearing house are considered conditionally paid by virtue of the clearing house charge against the payor bank. Sec, c.g., Hentz v. National City Bank of N.Y., 159 App. Div. 743, 144 N.Y. Supp. 979 (1st Dep't 1913); Mount Morris Bank v. Twenty Third Ward Bank, 172 N.Y. 244, 64 N.E. 810 (1902) ; Leary, Deferred Posting and Delayed Returns-The Current Check Collection Problem, 62 HARv. L. Rev. 905, 912-14 (1949); Moore, Sussman \& Corstvet, Drazeing Against Uncollected Checks: I, 45 YALE L.J. 1, 4, 5 (1935). The conditional payment became final at the end of the same business day, i.e., 3:00 P.M. Spanr, Clesinina and Collection of Checks 406 (1926). See, generally, Talbert, Clearing-House and Domestic Exchange Functions of the Federal Reserve Banks, 4 ACAD. of Por.. Scr. Proc. 192 (1913).

Checks received for payment through the mails must be paid or dishonored within 24 hours. Usually, if retained longer without settlement, the check is considercd paid. Negottable Instruments Law \$137. See Blackwelder v. Fergus Mator Co., 80 Mont. 374, 260 Pac. 734 (1927); Bull v. Novice State Bank, 250 S.W. 232 (Tex. Civ. App. 1923). Contra: Anderson Co. v. Hasha, 124 Cal. App. 23, 12 P.2d 20 (1st App. Dist. 1932) (the mere retention does not constitute acceptance). Cases are collected in Notes, 63 A.L.R. 1138 (1929) ; 68 A.L.R. 862 (1930).

12. All items received for payment through the clearing house had to be checked as to signatures and amount before the 3:00 P.M. deadline for dishonoring. Payment was deemed final when the deadline passed. Hallenback, Receiver v. Leimert, Receiver, 295 U,S. 116 (1935) ; Columbia-Knickerbocker Trust Co. v. Miller, 156 App. Div, 810, 142 N.Y. Supp. 440 (1st Dep't 1913) aff'd, 215 N.Y. 191, 109 N.E. 179 (1915). And if the bank subsequently discovered a forged drawer's signature or an averdraft, it could not recover payment from the recipient of the funds. Bank of the United States v. Bank: of Georgia, 10 Wheat. 333 (U.S. 1825) ; Security Nat. Bank of Sioux City v. Old Nat. Bank of Battle Creek, Mich., 241 Fed. 1 (8th Cir. 1917); Comment, Codification of the Rulc in Price v. Neal, 43 ILL. L, Rev. 823 (1949). Thus, bookkeepers had only five or six hours in which to check all items. The rush resulted in oversights, mistakes, and employecs missing their' regular lunch hour. For more detailed description of the resulting errors, see Leary, supra note 11 ; at 911, 916, 917.

13. "Posting" is the mechanical banking operation in which bookkeepers debit the accounts or ledgers of customers who have drawn checks upon the bank.

14. The American Bankers Association circulated a Modec Deferred Postina Statute (hereinafter cited as A.B.A. Moner. Statute) for adoption by the states. The Statute was drafted by the Bank.Management Commission of the Association, with the cooperation of a committee of attorneys of the Federal Reserve System. 
to revoke credits ${ }^{15}$ until midnight of the business day following receipt. $^{16}$ But although it has relieved the strain on hard-pressed

The status of deferred posting legislation, as of September 23, 1949, was as follows:

1. States in which the A.B.A. MIOdEL StatuTE was passed in identical or very similar form-34.

2. States having no form of deferred posting legislation-9: Kentucly, Louisian, Mississippi, Montana, New York, Tennessee, Washington, Wyoming, District of Columbia.

3. States having some other form of legislation not requiring credit on the day of receipt-6: Alabama, Florida, Mrassachusetts, North Carolina, Virginia, Texas.

4. States where the A.B.A. Modei Statute has not been enacted:

A. Legislature still in session but bill not introduced : Alabama, District of Columbia.

B. Legislature adjourned without enactment: Florida, Massachusetts, Mfontana, Nev York, North Carolina, Tennessee, Texas, Washington, Wyoming.

C. Legislature not in session this year: Kentucky, Louisiana, Mrississippi, Virginia. Communication to the YALE LAw JourRal from the Board of Governors of the Federal Reserve System, Washington, D.C., dated Oct. 25, 1949, in Yale Law Library. New York: has recently passed a modified deferred posting statute. N.Y. Times, April 2, 1950, §3, p. 1, col. 6 .

Upon suggestion of the A.B.A., the Board of Governors of the Federal Reserve System amended its rules relating to check clearing and collection to comply with the deferred posting practice. Regulation J, 12 CODE FED. REGs. $\$ 210.2$ et seq. (1939), as amended effective Jan. 1, 1949. See Amendments to Regulation J, 34 FED. REs. BuLL. 1472 (1948). For discussion of collection through Federal Reserve Banks, see Federal Reserve Bank of Richmond v. Early, 30 F.2d 198 (4th Cir. 1929) aff'd, 281 U.S. 84 (1930).

15. "In any case in which a bank receives, . . . a demand item . . . and gives credit therefor before midnight of the day of receipt, the bank may have until midnight of its next business day after receipt within which to dishonor or refuse payment of such item. $\therefore$. A.BA. MIODEL STATUte $\$ 1$. "The term 'credit' includes payment, remittance, advice of credit, or authorization to charge and, in cases where the item is received for deposit as well as for payment, also includes the making of appropriate entries to the receiving bank's general ledger without regard to whether the item is posted to individusl customers' ledgers. ... A.B.A. Miodel STATute $\$ 2(b)$.

Tentative credit on the day of receipt appears to have been included as a concession to the Federal Reserve Banks. They take the position that when cash items are sent to other banks they wish to have the remittance or credit on the day of receipt, even though "bad" items may be returned the following day. Unless this is done it will be necessary to lengthen availability schedules, i.e., the arbitrary dates on which the banks may consider items paid so far as having the funds available at the Federal Reserve Banls is concerned. Several Reserve Banks have recently shortened their availability schedules for the collection of checks drawn on banks outside their respective districts from three days to two days. As late as 1939, the availability period, in some instances was as long as seven days. The cut was the result of the use of air shipments and high speed sorting machines. Thus the member banks of the Federal Reserve clearing house will have the funds of the checl: available as reserve within two days, regardless of whether the check has actually been cleared or not. But a similar cut has not been extended to the collecting bank's customers. The depositing holder does not receive a credit which he can draw against until the checl: has actually been finally credited by the drawee. N.Y. Times, Feb. 5. 1950, §3, p. 1, col. 6 .

16. "Any credit so given, together with all related entries on the bools of the receiving bank, may be revoked by returning the item, or if the item is held for protest or at the time is lost or is not in the possession of the bank, by giving written notice of dishonor, non payment, or revocation; provided that such item or notice is dispatched in the 
banks, ${ }^{17}$ the statutory change has also extended the period of risk relationship existing between a checkholder and drawer. ${ }^{18}$

While adopting the Model Statute's deferred posting rule, the May, 1949 Draft of the proposed Uniform Commercial Code ${ }^{19}$ recognized the in-

mails or by other expeditious means not later than midnight of the bank's next business day after the item was received. . . . A bank, revoking credit pursuant to the authority of this Act, is entitled to refund of, or credit for, the amount of the item." A.B.A. ModEL STATUTE $\$ 1$.

The Statute limits deferred posting to demand items, of which checks are the most common form. "A check is generally defined as a draft or order upon a bank or banking house, purporting to be drawn upon a deposit of funds, for the payment at all events of a certain sum of money to the order of a certain person therein named, or to him or his order, or to bearer, and payable on demand." Regulation J, 12 CODE FED. REGS. $\$ 210.3$ n.1 (1939) as amended effective Jan. 1, 1949. Apparently non-demand items remain stibject to existing law.

The A.B.A. recognizes the essential difference, in legal treatment, between checks drawn on the depositary bank and checks drawn on some other bank. In the former case the Statute does not apply and existing rules still govern payment. Generally, when a check is cashed over the counter, the transaction is considered final and irrevocable cven as to a forged drawer's signature or overdrawn account. See note 1 supra.

17. Deferred posting is directed at avoiding the cumbersome and costly practice nccessitated by checking items received through the clearing house within five or six hours. The added day permits examination and posting of items in one continuous operation and tends toward greater efficiency and economy in bank operations.

For a detailed account of the beneficial effect of deferred posting on book-kceping departments, see Leary, supra note 11, at 916-17.

18. The STature merely states the time limit for revoking payment, i.e., midnight of the day after receipt. While there have been no cases directly in point subsequent to passage of the Model StatuTE, the cases under the old rule (3:00 P.M. of the day of receipt) usually held that payment is not final until the expiration of the time in which the drawce may revoke; consequently, stop-orders received before that time were effective. Sce, c.g., Hentz v. National City Bank of New York, 159 App. Div. 743, 746, 144 N.Y. Sup. 979 (1st Dep't 1913); German N. Bank v. The Farmers' D. N. Bank, 118 Pa. 294, 12 Atl. 303 (1888).

Some cases have held, however, that charge to the drawer's account amounted to final payment invalidating stop-orders received after the charge. See, c.g., Briggs v. Centrat Nat. Bank of New York, 89 N.Y. 182 (1882); Albers v. Commercial Bank, 9 Mo. App. 59 (1880). But cf. Farmers Bank of Morrill v. Stapelton, 118 Kan. 755, 236 Pac. 828 (1925) (acceptance communicated to payee by telegram held sufficient to deny stop-order despite no book-keeping entries).

Even if charge to the drawer's account is held to be determinative of the effectiveness of stop-orders, deferred posting still extends the holder's risk period because posting the various accounts generally takes place the following morning. See note $28 \mathrm{infra}$.

19. Amertcan Law Institute and NaT'i Conf. OF Cammissioners on UNIFORM State Laws, The Uniforar Commerctat Code Art. III \$3-630 (May, 1949 Draft) (hereinafter cited as A.L.I., Commercial Code ArT. III (May, 1949 Draft)). Tho CODE would repeal and supersede all present uniform acts and all legislation inconsistent therewith, including the NEGOTIABLE INSTRUMENTS LAw and any bank collection statutes. A.L.I., CoMMercial CODE ART. IX, § 9-102 (May, 1949 Draft).

For general discussion of the CODE and what it contemplates sec Beers, The Nczu Commercial Code, 32 J. Asr. Jud. Soc'y 107 (1948); Gilmore, On the Difficultics of Codifying Commercial Law, 57 Yale L.J. 1341 (1948); Comment, 45 Mrch. L. Rev. 1021 (1947). 
creased hardship the Statute imposes on the holder and compensated him by giving his item priority over stop-orders and other legal notices received by the drawee after his check has arrived. $\$$ Thus, under this proposal, if a check reaches the drawee bank at 9:00 A.M., and a stop-order at 10:00 A.M., the check would be payable; whereas under the Model Statute the notice would have defeated payment if received anytime before final credit is extended at midnight of the following day. The holder's risks are thereby diminished while banks retain the advantages of an extended posting period.

The priority theory of the Code, however, was criticized as being difficult of administration. ${ }^{21}$ The exact time a check is received would become paramount and it was said that many banks, especially those that handle a large daily volume, could ascertain the time only with difficulty. Most checks are received in bulk. To require marking each check when received would be expensive because of the great number of checks handled each day. ${ }^{22}$ And if individual checks are not marked, it would be necessary to

20. "[A]n item properly payable when received takes priority for payment over all subsequently received notices, stop-orders, or legal process. ..." A.L.I. Comonncan CoDE ART. III \$3-629(1) (May, 1949 Draft). No provision is made for determining priority in the situation in which the stop notice and check are received in the same mail or night depositary receptacle. Apparently the question is left to subsequent judicial decision.

In Comment 5 to A.L.I. Comarercial Code Arr. III \$3-414(5) (Afay, 1949 Draft) the drafters expressly state that the reason for the priority rule is to avoid subjecting the holder to a greater risk of attachment or other legal process as a result of the delay occasioned by deferred posting.

Further protection is afforded the holder by $\$ 3-416:$ :(1) The death of the drawer does not revoke the authority of the drawee to pay drafts until the drawee has lnowledge of the death. (2) Even with such knowledge a bank may pay checks for ten days aiter the date of death unless it is directed to stop payment of checks by some person chiming an interest in the estate." The purpose of this section, as stated in Comment 3 thereto, "is to permit holders of checks given shortly before death to cash them without the necessity of filing a claim in probate." Since the check is normally given in immediate payment of an obligation and will rarely be revoked, there is no justification for burdening the holder, the executor, the court and the bank with needless formality.

21. The assistant counsel of the Federal Reserve Bank of New York claims that the priority provision of the May, 1949 Draft might prove diffcult for banks to put into practice. Communication to the Yale LAw Journal from the Federal Reserve Bank of New York, New York, N. Y., dated Nov. 15, 1949, in Yale Law Library.

22. "A very large bank in New York City handled about 340,000 incoming cash items in a single day, and a medium sized bank handled 148,000 incoming items. A study of 82 small banks, scattered over 37 states, shows that even the midgets of the banling world handle between 700 and 3,000 incoming items a day. These figures prove a fact well known to bankers, but which has not been given as much recognition in judicial thinking as it should, namely, that no bank handles or collects 'a checl'-it handles checks in bulk. It must do so, not only to reduce the cost of handling to a fraction of a cent per item, but also to comply with the rules of law requiring prompt presentment. Collection of cash items is, and must be, a fast moving, streamlined, bulk handling operation." Leary, Deferred Posting and Delayed Returns-The Current Check Collection Problcm, 62 HARv. I. Rev. 905, 908-9 (1949). 
trace back an,item and determine its time of receipt from a cash sheet identifying the group of checks with which it was received. ${ }^{23}$

Probably because of this criticism, the Spring, 1950 Draft of the Commercial Code alters the priority rule. Stop-orders and other legal notices are effective under the new section until midnight of the day of receipt of the check unless final payment or charge to the drawer's account occurs prior to arrival of the notice. ${ }^{24}$ Hence, the exact time a cash item arrives no longer need be determined, and the necessity for trace-back and marking checks at time of receipt is eliminated.

In one respect, however, the priority rule remains unchanged under the latest draft. The former provision of the Code had relieved the holder of the risk of bank failure by extending Federal Deposit Insurance to him during the time the check is in the hands of the drawee bank; ${ }^{25}$ if the drawee fails before finally crediting its correspondent's account, the holder at his election ${ }^{26}$ may consider himself a depositor of the drawee and receive coverage up to $\$ 5000$ if the check is otherwise payable. For insurance coverage purposes no.special trace-back or marking would be necessary. All instruments in the possession of the bankrupt drawee at the time its doors were closed would automatically receive coverage. No administrative objection was urged against this aspect of the priority rule and the latest Code draft perpetuates it. ${ }^{27}$

- Despite this exception which protects holders against the drawee bank's insolvency, the compensating factor of the May, 1949 Draft remains largdy thwarted by the new provisions. The older draft extended protection to holders when the check was received by the drawee bank. But the new rule decreases that protection by sanctioning stop-orders and other notices until

23. Whether a stop-order or other notice is effective against a particular check usually cannot be determined until the check is ready for posting. At this point the bookkeeper, or some other clerk, would have to trace the item back to determine the exact time of receipt, since the time is not marked on the check itself. The time of receipt of the stoporder and the check must then be compared to determine which will be given effect.

24. American Law Institute and Nat' Conf. of Commissioners on Unifomas State laws, The Uniform Commercial Code Art. III (Spring, 1950 Draft) \$4-402(3) (hereinafter cited as A.L.I. Commerctal Code Art. III (Spring, 1950 Draft)).

25. A.L.I. Comarercial Code Art. III $\$ 3-629$ (1) (May, 1949 Draft). It is to the drawer's benefit, as well as the holder's that the check be deemed finally pald at the earliest possible moment so as to secure to the holder Federal Deposit Insurance in case the drawiee fails. The holder will often prefer recovery from the Federal Deposit Insurance Corporation to recourse against the drawer. The latter course involves risks such as death and insolvency.

26. A.L.I., Commerctal Code Art. III, §3-629(3) (May, 1949 Draft). The holder may elect to treat the check as unpaid and pursue the drawer instead. The option will bo effective only if written notice is given the drawee and prior partics within 10 days after the holder has received notice of the facts. In those instances where the check is over $\$ 5,000$, and thus not fully covered by Federal Deposit Insurance, this provision permits full recovery from the drawer.

27. A.L.I. Commercial Code ART. III $\S \S 401$ (1) (4) (5) (Spring, 1950 Draft). 
midnight of the day on which the check arrives, unless a charge to the drawer's account or final credit has been extended prior to receipt of the notice. In reality, the latter proviso is meaningless since under deferred posting the charge and irrevocable credit are usually made after midnight.23 Hence, in most instances, the holder's risks of stop-payment, garnishment, and notice of drawer's death would be extended until midnight of the day of receipt of the check - as much as an additional fifteen hours. ${ }^{2}$

Critics, moreover, probably overstate the administrative burden and expense the priority theory would impose. Time-stamping all checks individually would, if carried out as a separate operation, cause a substantial increase in handling expense. But checks received in bulk through a clearing house constitute the majority of those handled daily, ${ }^{20}$ and their time of receipt could with relative facility be indicated on the cash sheet accompanying such checks. Fewer checks arrive separately-over the counter or through the mails--and only these would require individual handling. While time-stamping of over-the-counter checks would impose an added operation on the receiving teller, these items require individual handling in any case, and hence the hardship would be minimal. As for mailed items, some banls already mark their time of receipt, so that no extra expense would arise. And instituting an incoming mail time-stamping device entails but little additional cost.

Nor would the necessity for trace-backs give rise to inordinate expense. Checks are traced only when the time of arrival has to be checked against arrival of stop-orders or other notices to determine which came first. ${ }^{31}$ Only a small percentage-less than $0.5 \%$ on a liberal estimate-of all checks received for payment would require trace-backs. ${ }^{32}$ Drawers do not issue stop-

28. The extension of the payment deadline was instituted for the purpose of permitting bookkeepers to post accounts more efficiently. This process is now accomplished by sorting clerks, who prepare the checks for posting on the day of receipt, and by the bookkeepers, who do the actual posting on the following morning. See Leary, Deferred Posting and Delayed Retursu-The Current Check Collections Problem, 62 HAnv. L. REv. 905,917 (1949). Extension of irrevocable credit by the drawee bank wilt also be deferred until the day after the day of receipt of the check because examination of the drawer's account precedes payment.

29. While the MIODEL STATUTE extended the holder's risk period to midnight of the following day, and the May, 1949 draft of the CODE shortened it to time of receipt, this new provision would decrease the period only until midnight of the day of receipt. Thus, if a check arrived at the drawee bank at 9:00 A.Mr., the holder's risk period would remain fifteen hours longer than the Miay, 1949 Draft would have allowed.

30. See Moore, Sussman \& Corstvet, Drawing Against Uncollected Checl:s: I, 45 YALE L.J. 1, 17 (1935).

31. Trace-backs would not be required where checks have no notices against them which could defeat payment. These would be handled in the regular course of business routine. No expense is involved here since posting is a normal operation.

32. The great majority of checks are never dishonored. "In 1943 an examination of $1,489,051$ items handled by 9 banks showed a total of 7,148 items returned or $0.48 \%^{\circ}$ of the total presented. Too Mlany Dishonored Items, 60 BANErRs Moxtruly 157 (1943). 
orders indiscriminately, and garnishment is a remedy of last resort for creditors. But even if the expense should prove unduly burdensome-a contingency seemingly remote-the drawee bank could always avoid it. The expense could be shifted to troublesome accounts by charging the individual depositor for the extra service involved in death-notice, garnishment, and stop-order trace-backs. ${ }^{33}$

Actually, the problem of the holder's risk period arises because a check is not an assignment of funds. ${ }^{34}$ If it were, the holder would be protected against subsequent stop-notices from the moment the check was issued. ${ }^{30}$ The priority provision of the May, 1949 Draft of the Commercial Code went a long way toward making a check an assignment by protecting the holder from the time his check arrived at the drawee bank. ${ }^{36}$ Although the check still operates as a partial assignment under the Spring, 1950 Draft, it does so only between midnight of the day of receipt and midnight of the following day. There is no substantial reason, however, why the holder's protection should be diminished in this way. Admittedly, deferred posting is necessary to promote banking efficiency, since it eliminates the hastecreated posting errors common to pre-war banking practice. But this saving should not be made at the sole expense of check-holders.

A study of $148,560,071$ items handled by one Federal Reserve Bank during 1946 disclosed a total of only 589,818 returns or $0.40 \%$." Leary, supra note 28 , at 912 n.12.

These returned items include checks with deficiencies in signatures or overdrafts. Thus the percentage returned because of stop-orders, garnishments, or notice of drawer's death is actually less than represented by the percentages.

33. This practice is widely employed by many banks today. The Cope would expressly sanction such extra charge. A.L.I. CoMmercIal CODE ART. III \$4-202(3) (Spring, 1950 Draft).

34. See note 2 supra. Both drafts of the CODE adopt the non-assignment rulc. A.L.I. Commerctal Code Art. III \& 3-409(1) (May, 1949 Draft); A.L.I. Comulerctaz' Code ART. III \& 3-409(1) (Spring, 1950 Draft).

35. If the assignment is completely gratuitous, Section 158 of the Restatement of Contracts permits the assignor (drawer) to revoke the assignment. Thus payment may be stopped. Difficulty arises, however, in that the drawee bank, upon receipt of the stoporder, has no way of knowing if the assignment is gratuitous or for valuable consideration. The dilemma thereby created is one of the reasons for the reluctance to consider a clicek an assignment of funds. Pros and cons of the non-assignment rule, however, are beyond the scope of this Note.

36. As soon as the holder's check arrived at the drawee bank, the drawer and those claiming through him could no longer control payment. The holder had a prior right to the funds of the drawer. 